\title{
Redefined Families and Subsystems: Reading Kinship and Hierarchical Structures in Select Hijra Autobiographies
}

\author{
Tanupriya \\ Assistant Professor, Department of Languages, School of Social Sciences and Humanities, \\ Christ (Deemed to be University), Delhi NCR, E-mail: tanupriya@christuniversity.in
}

\begin{abstract}
Hijras or transwomen in India are gendered identities, but their identities cannot be reduced to the conceptual framework and analysis of 'sex', 'gender' and 'sexuality'. Being the minority in India, transgender lives intersect with caste, class, kinship and hierarchy. The study locates these intersections within the scope of the select hijra autobiographies; The Truth About Me: A Hijra Life Story by A. Revathi and I am Vidya by Vidya. The study looks at the notions of 'family' which are traditionally woven in heteronormative and patriarchal setups. It examines the gharanas system or subsystems in hijra communities that redefines the structures and hierarchies of the family, and designating the fellow elder hijras with the relation of mata (mother) and cela (disciple), thus forming a kinship which is located beyond the caste, class and religious structures. The emphasis is to study how families are inserted in heteronormative perspectives and argues a redefining of the notion of 'family', and to establish and recognize the newer perspectives on 'family' which lies outside the traditional setup.
\end{abstract}

Keywords: Caste, Class, Family, Subsystems

\section{Introduction}

Hijra identities are culturally conceptualized and provide a positive context to alternative sex and gender roles in Indian context. Roots of their presence are visible through various mythological figures in Hinduism. Serena Nanda in her ethnography Neither Man nor Woman states that "notions of hijra, found in classical Hinduism, were divided into four categories: the male eunuch, the hermaphrodite, the testicle voided, and the female eunuch" (Nanda 1990: 177). According to Zwilling and Sweet (1996), individuals belonging to third nature, transposed genders, sexual masquerades abound in the Hindu mythological and folkloric narratives. Historian Shaun Tougher in "In or out?: Origins of Court Eunuchs" notes "the predominant focus of the historical study of the eunuch tended to be "their place and function at royal and imperial courts" (Tougher 2002: 143). The presence of eunuchs is noted in the court systems of various empires as political advisors, powerful administrators, and chamberlains, as well as trusted generals and guardians of the harim, or the inner female domain. Colonial literature mostly focused less on hijras as 'slaves' or the 'third sex' than on their status as one of the scores of castes/tribes in India. They were stratified according to gender and religion. Representations of hijras in rituals, rites to passage ceremonies, folktales, mythology, urban legends, and folk art have allowed them to create a culturally significant, institutionalized, and marginalized space within Indian societies. Gayatri Reddy in her ethnography With Respect to Sex: Negotiating the Hijra Identities in India mentions that "with more than five million hijras, this community has gained a new sort of notoriety".

(C) AesthetixMS 2020. This Open Access article is published under a Creative Commons Attribution Non-Commercial 4.0 International License (http://creativecommons.org/licenses/by-nc/4.0/), which permits non-commercial re-use, distribution, and reproduction in any medium, provided the original work is properly cited. For citation use the DOI. For commercial re-use, please contact editor@rupkatha.com. 
Scholars researching LGBTQ issues have put them forward as "an ideal case in the transnational system of 'alternative' gender/sexuality" (Reddy 2006: 2).

Third Gender' is used to refer to hijras in India. Originally, the term 'third gender' was introduced in 1975 by M. Kay Martin and Barbara Voorhies to denote transgender individuals. They used the term to draw attention to the ethnographic evidence that gender categories in some cultures could not be adequately explained with a two-gendered framework. This evidence had profound implications on feminist and gender theorists as well as for social movements and political activists in the United States, as it allowed them to think outside a dichotomous gender system. 'Third gender' then, began to be applied to behaviors that transcended or challenged male-female codes or norms. It was also applied to societies that seemed to provide institutionalized intermediate gender concepts and practices. In India, the term 'third gender' came to practice after the verdict of the Supreme Court of India on April 15, 2014, and recognized the transgender individuals as 'third gender.' Gilbert Herdt, an American cultural anthropologist, challenges the prominence of sexual dimorphism in the Western sex and gender discourse. His work Third Sex, Third Gender (1994) is a collection of essays that analyse the social and cultural context of gender identities, drawing on the studies of the American Indian berdache, Indian 'hijras', 'hermaphrodites' in Melanesia, and 'third gender' in Indonesia. Europeans also described gender-variant natives with the French word berdache, derived from the Persian root. Will Roscoe (1998) identifies that there is no single concept of berdache among the Native Americans; rather he notes that

... the diversity of their languages, ideas, and culture resulted in the use of many different terms for berdache. He classifies male berdache as a third gender and female berdache as a fourth gender. (Roscoe 1998: 71)

Hijra identities are seen as marginalized gendered identities and have been analysed in the framework of sex and gender, as their identity lies outside the binary paradigm. But, looking at the social organization, their identities are more complicatedly built around other intersections of caste, class, kinship, and hierarchy. Being the liminal identities, their transition of from sex to gender cannot be ignored along with their formation of identities in the system of surveillance such as caste, class and hierarchy. Hijras are believed to renounce sexual desires by undergoing a sacrificial emasculation, i.e., an excision of the genitalia which is dedicated to Bahuchara Mata. Only a few of them are born as 'intersexed' or people born with ambiguous genitalia. When one desires to be a part of the hijra community, a few willing hijras' take part in an initiation rite called nirvan in which the scrotum, testicles, and penis are removed. While neither castration nor nirvan rites necessarily mean renouncement of sexuality or sexual desire. It merely means the renouncement of male penetrative sexual performance. It is believed that the act of nirvan socially bestows sacred powers to some hijras as a result of the transmutation of sexual energy. This ritual is part of hijra community is done in accordance with the particular hijra clan that they are related to. Apart from being the liminal identities, their identities are located separately within the family structure, where the heteronormative family is considered as the ideal norm. There settles the importance of hijra kinship and bonds i.e. social arrangements and subsystems or gharanas that becomes a major part of hijra identity. Family, which is also generally regarded as a social institution, is created by the biological kinship, marriage or adoption, etc. The conceptualization of family is also influenced by the culture, religion, and the law. This study tries to look into the redefined subsystems that are part of hijra culture and community, where their authenticity is also evaluated in the terms of belongingness with the gharanas (household), and the mata (mother) and cela (disciple) relationships. The analysis and understanding of these 
overlapping identities within and outside the subsystem to understand their complexities is attempted within the scope of select hijra autobiographies, A. Revathi's The Truth About Me, and Vidya's I am Vidya.

\section{Kinship Structures, Subsystems, and Gharanas: An Analysis}

Gayatri Reddy in With Respect to Sex: Negotiating Hijra Identity in South India (2006) mentions that past studies on family and kinship have focused on marriage or alliance as the fulcrum of relatedness and the central institution of kinship relations (145). Hijra identities can be located beyond the biological kinship and are seen to be established outside the frameworks of caste, class and identity. Hijra communities or clan are the subsystems within the larger system that society is. Revathi's autobiography mentions,

A hijra can become a chela to anyone, but must ultimately live only with her guru and abide by what they say. A hijra must necessarily follow the rules of the community. (99)

This situates the subsystems that are created in hijra household are also built on power structures, and her autobiography also mentions the discrimination and stigma in the hijra community.

In TheTruth About Me by A. Revathi the terms thozhis, kurathis, pottais, devadasis, ghorimoorathan, pinjus denote the phases that Revathi went through. Thozhis is a Tamil term used to refer to each-other as friend, in the hijra clan, to show love and affection, kurathis are female tribal gypsies in Tamil Nadu and South of India. Pottais are cross dressers or sari-clad feminine man; devadasis is used in the context of renouncing the sexual practices after nirvana and ghorimoorathan is a person who is becoming chela for the first time. Pinjus is used by the older women in hijra clan, to address the young and tender age members. The fragments and trajectories of Revathi's identity can be traced through these terms and is evident in her autobiography, where she dresses like 'female' for the Mariamman festival in their village and agrees to the role of kurathi. "They asked me if I would like to dress up as a kurathi, since I appeared feminine anyway" (Revathi: 12). Here, 'performance' and 'performativity' both are at play, she is involved in theatrical 'performance' of being a kurathi, which is at the same time enacting out the desired gender role and hence suggests 'performativity'. "To the world, it appeared that I was dressing up and playing a woman, but inside, I felt I was a woman" (ibid: 12). After, realizing about her 'female self', she spent most of her evenings with her new friends who were "like" them (ibid: 18). "We could fold up our lungis...I guess these men were more my female comrades than mere friends; my thozhis. Being thozhis was a phase in her life, where performativity was carried out through language i.e., “...we address each other as women” (ibid: 18). Being a pottai, was another phase, where she hasn't undergone nirvan, and yet she was clad like women. She mentions, "...my guru told me that I ought to be careful and make sure that my penis was not visible when I peed" (ibid: 24). She was asked to be careful until she underwent nirvan. After getting settled in a hijra household, hijras were asked to dance for a living on several occasions, wearing female clothes, where they were mocked at almost all the time. "We got stared at a lot, and I heard people ask rather loudly whether we were men or women or Number 9 or devadasis" (Revathi 2010: 29). Devadasi cannot be seen as an identity of Revathi, it was something that she was called, when she was not operated and danced on the streets. Revathi in her autobiographical narrative talks about the 'guru-chela' system prevalent in Tamil Nadu, though every city has its own hijra household with a different set of rules, functioning, and culture. To be a chela, one has to perform a certain set of rituals to become a part of that household. In her earlier household in Mumbai, she wasn't a chela to anyone but in Tamilnadu she was accepted as 
a chela by the seven naiks of the household. Ghoorimoorathan is a person who is becoming a chela for the first time. It could be said that hijra household follows a different hierarchical power structure where the head (superior) makes the rules, and the chela (subordinate) follows them. Each household has its own reeth, or system; as Revathi mentions:

The naiks called the jamaat to order and announce loudly for everyone to hear that Revathi was being chela...at this, all present clapped their hands. I was asked to do paampaduthi (touching feet to show respect) to all elders. They call it reeth, this system of consecrating chelas (Revathi 2010: 63).

Hijra household operates on defined power structures that could be related to Foucault's notions of power that, it is 'everywhere, diffused and embodied in discourse, knowledge, and regimes of truth'. He argues that 'power is immanent in all social relations, and all social relations, are relations of power, whether in families, or in all hierarchies of government'. Foucault's concept of 'power' has much in common with Althusser's 'ideology' and Gramsci's 'hegemony' as it rules by consent. Foucault's 'power', just like 'ideology' and 'hegemony', derives its strength from the fact that the subjects deeply believe in what it tells them, for it gives a sense of belonging and contributes to their well-being. He maintains that 'methods of power operate not by right, but by technique, not by law, but by normalization, not by punishment, but by control' (Foucault 1978). Hijra household is an apt example for this as, hijras need a place where they can be guided by their own community towards their betterment. In the household, Revathi was referred to as pinjus for being the youngest. So, the term, to some extent describes her journey towards identity formation. Revathi's autobiography provides instances of unity and togetherness that a family exhibits, but also brings out the contrast of power structures through the guru and chela relationships.

In case of hijra autobiographies, there is a linear fashion in identifying themselves as female from childhood, but Revathi and Vidya's autobiographical narratives are gripping, which mentions about the struggles with the family, violence inflicted on them, finding space in hijra household, struggles with education and sex work. Vidya also exhibits her struggles through her autobiography, the struggle of leaving her louse and joining the hijra community. She mentions "I have wholeheartedly accepted the sorority of transgenders" (75). Her autobiography also mentions about the power structures that operate within the household, "They demand implicit obedience, they don't tolerate you sitting with them on an equal level. Touching feet is another standard expectation" (74). Not only the autobiographies exhibit a sense of kinship structures and subsystems but also bring forward the power and hierarchical structures that operate in the household. On the other hand, these subsytems also challenge the heteronormative concepts of family and imbibe a nani, mata and cela female relationships. Gayatri (2006) states, "In none of these analyses do procreative kinship ideologies centered on the institution of marriage occupy the primary node of hijra relatedness" (150). The institution of marriage is clearly not the fulcrum of hijra kinships. Family, for hijras, was defined primarily in terms of "other hijras, especially one's guru lineage; relationships with other hijras (and kotis), rather than natal family or "husbands" and their kin, constituted the most important relational bonds for hijras. These are our people now" (151). In similar context, Revathi mentions,

What would a pottai like you want with marriage? You ought not have lusted after a man. Didn't I tell you that you must not feel this man love? Once you are a pottai, it's best that you set yourself up with a chela. (129) 
This suggests that bonds of marriage aren't a part of hijra kinship. The autobiographies, also exhibit a sense of power structures that operates within in household by the elderly in the community. Implicit is the contrast of power and kinship relationships that are a part of hijra community and subsystems.

\section{Conclusion}

The paper examines and investigates the understanding of subsystems and kinship structures that operate in the hijra community and their clan. It further discusses the interlinked power structures in the community that is operated by the elderly, but also reinforces that hijra bonds are also an important part in shaping the identity of hijras. Reddy (2006) states, "Central to this understanding of family is a notion of caring, indexed principally through a temporal (and spatial) dimension of "being there" rather than biogenetic connections (through "blood" and marriage)" (150). It highlights an inherent power structure that is a part of these hijra subsystems within the social organization. Hijra identities are subject to power in the society and within the subsystems as well, but there is larger importance that has been placed on hijra kinships and bonds. This is suggestive of an implicit contrast of power and kinship relationships that are a part of the hijra community and subsystems.

\section{References}

Foucault, Michel. (1978). The History of Sexuality: An Introduction, Vintage, New York.

---. (1995). Discipline and Punish: The Birth of the Prison, Vintage Books, New York.

Herdt, Gilbert. (1996). Third Sex, Third Gender: Beyond Sexual Dimorphism in Culture and History, Zone Books,New York.

Martin, M. Kay and Barbara Voohries. (1975). Female of the Species, Columbia University Press, Columbia.

Nanda, Serena. (1990). Neither Man nor Woman: The Hijras of India, Wadsworth Publishing House, London.

Reddy, Gayatri. (2006). With Respect to Sex: Negotiating Hijra Identity in South India, Yoda Press, New Delhi.

Revathi, A. (2010). The Truth About Me, Penguin Books, New Delhi.

Sweet, M. J. and Zwilling, L. (1996). "Like a City Ablaze': The Third Sex and the Creation of Sexuality in Jain Religious Literature." Journal of the History of Sexuality, 6(3), 359-84.

Roscoe, Will. (1998). Changing Ones: Third and Fourth Genders in Native North America, St. Martin's Press, New York.

Tougher, Shaun. (2002). "In or Out?: Origins of Court Eunuchs." Eunuch in Antiquity and Beyond, S. Tougher, (ed.), Duckworth and Classical Press of Wales, London.

Vidya. (2007). I am Vidya, Oxygen Books, Chennai. 